MATEC Web of Conferences 53, 01030 (2016)

DOI: $10.1051 /$ matecconf $/ 20165301030$

(C) Owned by the authors, published by EDP Sciences, 2016

\title{
Complex Testing of the Bridges
}

\author{
Adrijana Savić ${ }^{1, a}$ \\ ${ }^{1}$ Direkcija za urbanizam i izgradnju grada Leskovca, 18000 Niš, Srbija
}

\begin{abstract}
This article describes the process of examining bridges. AB road bridge, founded on the columns by the Karpoš system and damaged due to erosive action of the river, is given as an example. The first tests of the bridge are conducted on the impact load of V 300 , because of the appearance of longitudinal cracks. The results of the columns testing are presented in this paper, as well as the rehabilitation measures thus increasing the load capacity of the column.
\end{abstract}

\section{Introduction}

Systematic and complex testing of bridges allows timely notice of dangerous irregularities in their structure. Properly implemented, the rehabilitation measures are able to fully establish the performance of a bridge and thus to extend the term of their exploitation [1-4]

Traditionally, the testing involves the following steps [5-12]:

1) Introduction to the technical documentation.

2) Visual observation of the bridge structure.

3) Instrumental testing's. Conducted with the aim to assess the overlap with the project of geometrical proportions, also with the physical-mechanical properties of the applied materials. Evaluation of transport - exploitation characteristics of the pavement in the bridge is performed by geodetic surveying of the road surface $[6,7,8]$.

Composition of the basic instrumental tests:

1) Concrete strength is determined under the following non-destructive testing methods: shearing, rebound hammer testing and ultrasonic tool. Fig. $1(\mathrm{a}, \mathrm{b}, \mathrm{c})$

2) Concrete shield layer determination. Fig. 2 (a)

3) Water resistance of concrete by air permeability degree. Fig. 2 (b)

4) Concrete moister determination. Fig. 2 (c)

5) Determination of strains in pre-stressed reinforcement. Fig. 3 (a)

6) Determination of strains is reinforcement wires using guy method. Fig. 3 (b)

7) Estimation of degree of corrosion according to the method electric potential measurement method. Fig. 3 (c)

8) Temperature determination of the bridge structure members using thermal imaging device. Fig. 4 (a)

9) Determination of adhesion of various surfaces and reinforcing materials to structure members. Fig. 4 (b)

10) Determination of paint-coat thickness under a non-destructive testing method. Fig. 4 (c)

\footnotetext{
${ }^{a}$ Corresponding author: sadrijana@bk.ru
} 
11) Determination of concrete carbonization depth. Fig. 5 (a)

12) Determination of crack depth. Fig. 5 (b)

13) Land survey measurements execution (axial and cross-section profiles of traffic-bearing determination, deck surveying along bottom surfaces, checking whether actual marking points correspond to designed ones). Fig. 5 (c) [13-18]
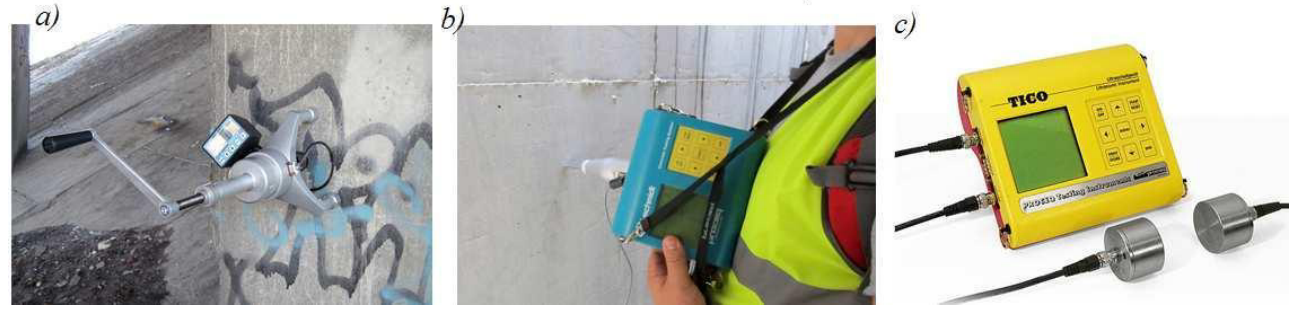

Figure 1. Concrete strength determination under a non-destructive testing method
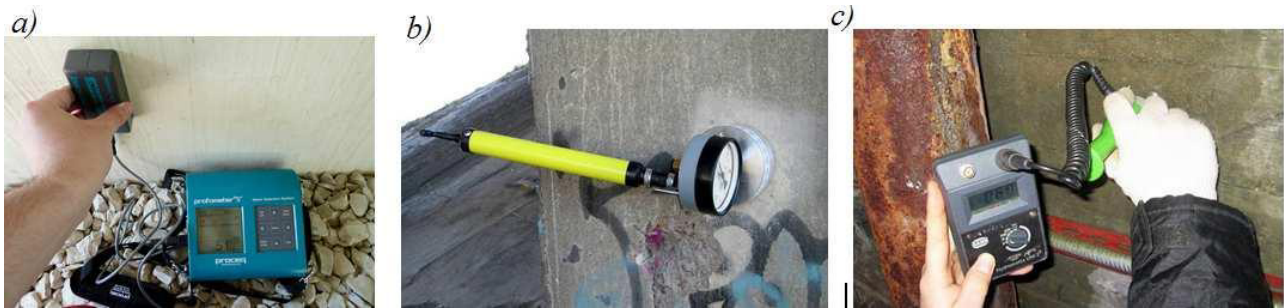

Figure 2. Determination of concrete shield layer, water resistance and moisture

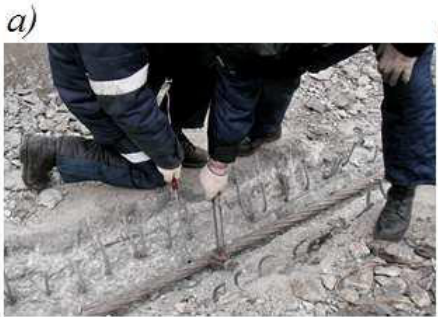

b)

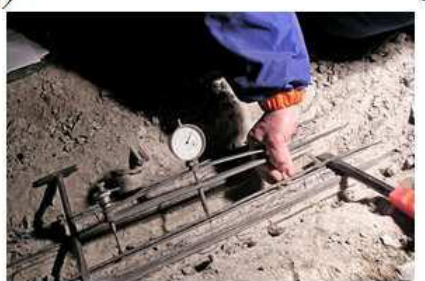

b)

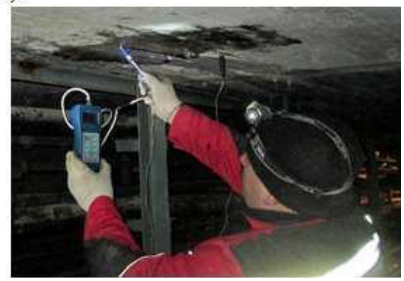

Figure 3. Determination reinforcement strains and estimation of corrosion degree
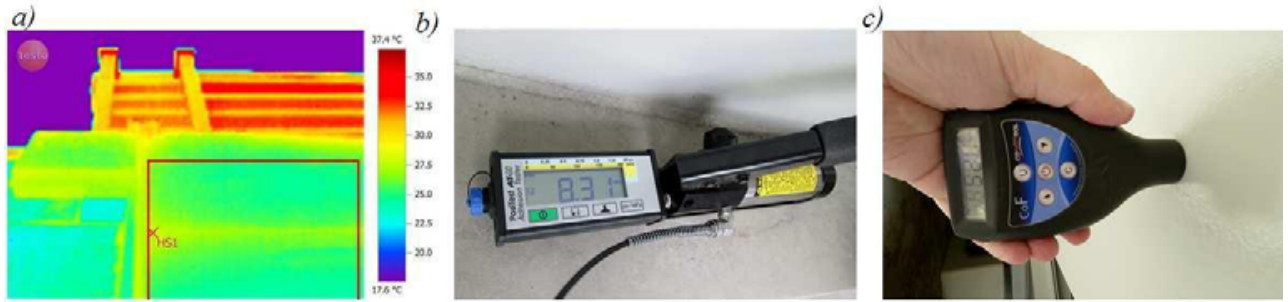

Figure 4. Thermal imaging survey, surfaces adhesion determination, paint-coat thickness determination
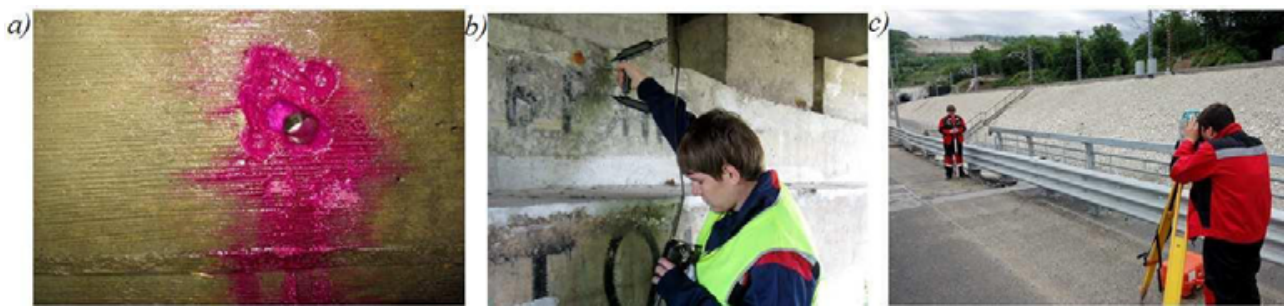
Figure 5. Determination of concrete carbonization depth, crack depth and land survey measurements.

\section{Testing of the bridge, constructed in Predejane (Serbia), which suffered the corrosive effects of the river.}

\subsection{Disposition of the bridge.}

AB Road Bridge is located in the village of Predejane over the South Morava river and consists of eight fields $(8 \times 10,0 \mathrm{~m})$. The width of the road lane is $4,0 \mathrm{~m}$. The bridge is founded on the columns by the system Karposh [19, 21]. And under each support are the four columns. Due to the erosive action of the river bed, since the South Morava has torrential character, there was some damages in the 5th, 6th and 7th row, so the buckling length in those sections is far larger than the calculational, which is 5.0m (Fig. 6, 7, 8).

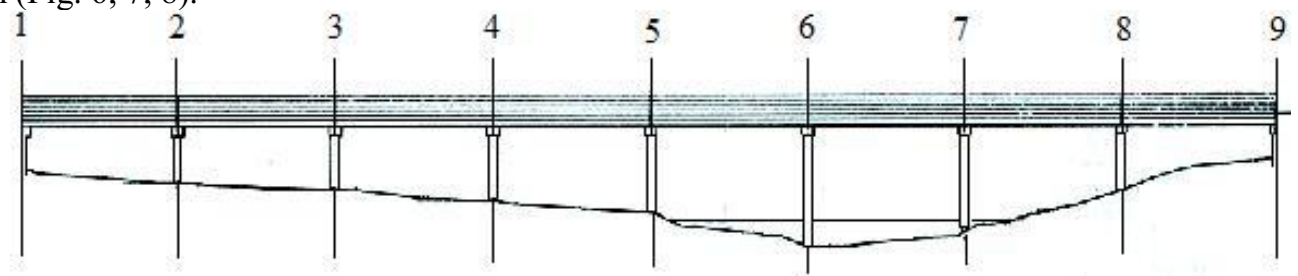

Figure 6. The scheme of the bridge
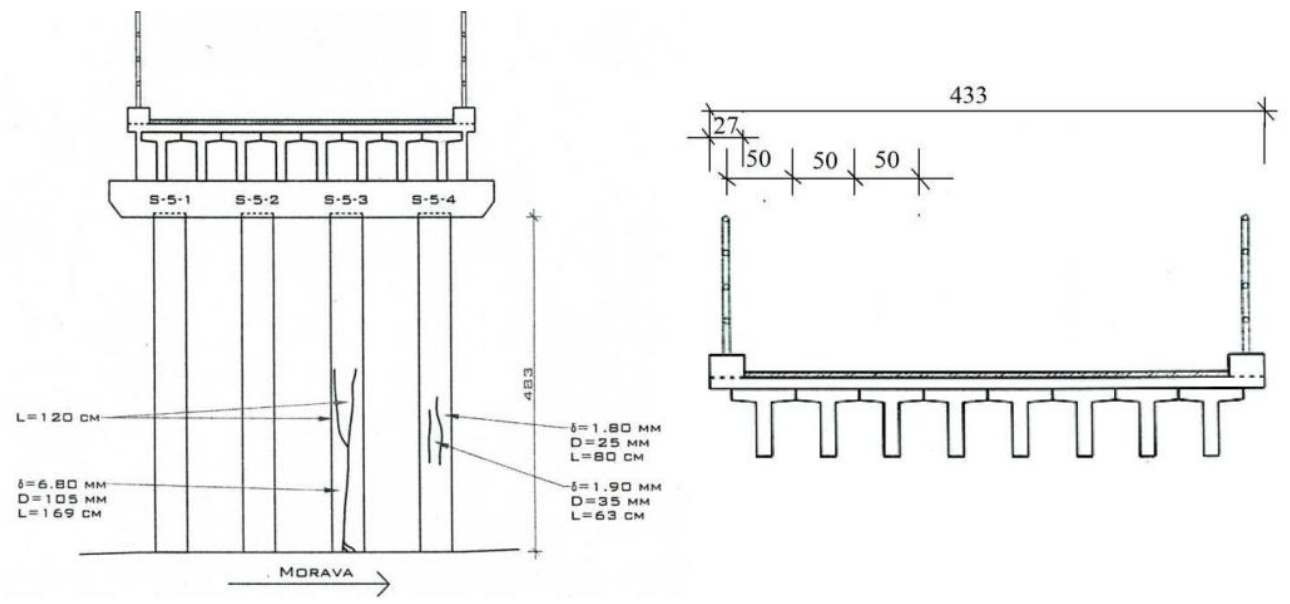

Figure 7. Cross-sectional and cracks on the pillars - Axis 5
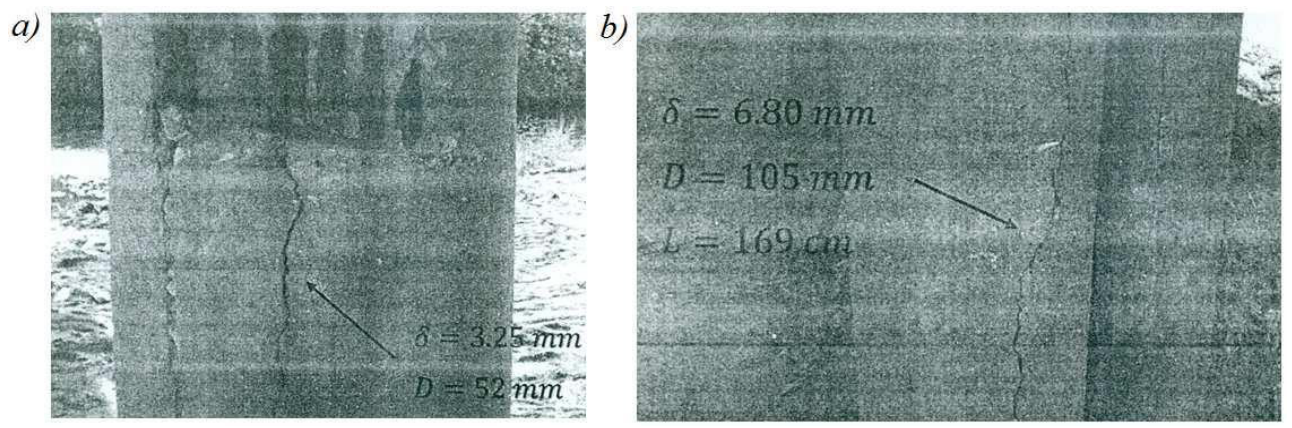

Figure 8. a) Corrosion of the reinforcement and cracks of the column S-4-1and b) Cracks on the column S-5-3 


\subsection{The conducted tests}

Considering that large longitudinal cracks on some piles of the bridge had appeared, we started a pilot test of the V300 vehicle in a different mode of the vehicle motion and in a position which depended on the line of influential. The paper presents the results of columns testing in the row no.5 from the perspective of the vehicle motion and braking over the tested piles [22-29].

The measuring sensor V50, from Hottinger Baldwin company, was set in half of the range, in order to monitor the movements due to buckling and slenderness of approximately $1=6.50 \mathrm{~m}$.

The results of recorded diagrams in the program are by the system Spider - CatMan. When the force $\mathrm{P}$ acts, it is clear that the reactions of the vehicle at the point approximately correspond to half of the range of the pile, causing a change of the elastic line, which indicates that there is a second tone of oscillation [30-37]. The appearance of opening cracks in the investigated column, is also noticed, which further threatens the local stability of the bridge as a whole (Fig. 9).



Figure 9. Diagram of the horizontal shift of the column

\section{Static calculation of the columns with strengthens in 5th, 6th and 7th rows (Fig.10).}

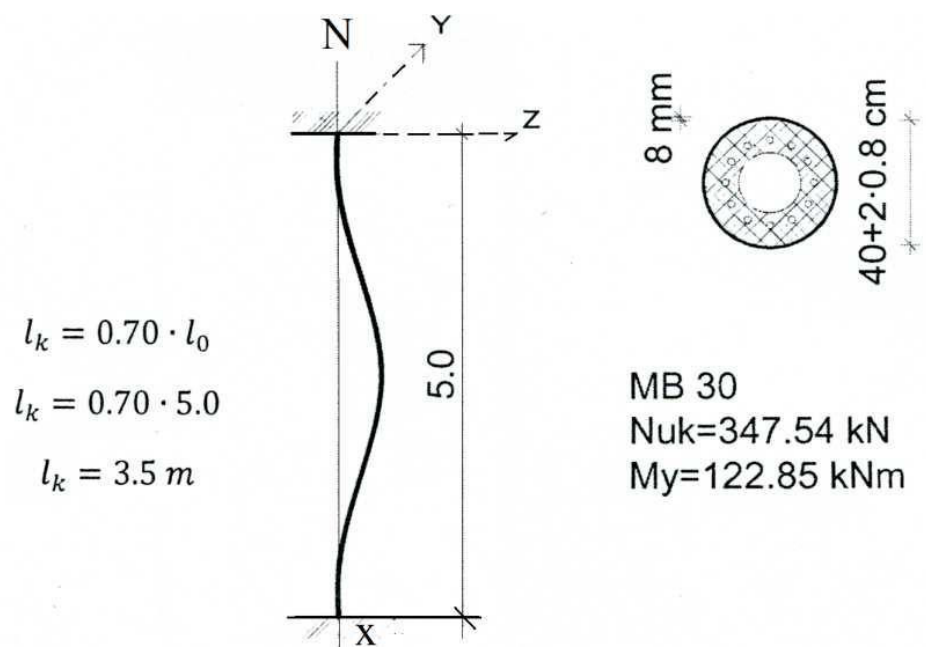

Figure 10. Static calculation of the columns

Other elements of the bridge superstructure weren't considered for possible rehabilitation measures, since they are in good condition, as such they can serve their purpose [38]. 
Adopting C.0361

Limits of stretching:

$\beta_{\mathrm{sa}}=24 \mathrm{kN} / \mathrm{cm}^{2}$

MB 30

Calculated value of concrete strength:

$\beta_{\mathrm{r}}=0.7 * 3=2.1 \mathrm{kN} / \mathrm{cm}^{2}$

GA 240/360 - 12 Ø22

$$
\begin{gathered}
A_{b}=\frac{40^{2} \pi}{4}-\frac{19^{2} \pi}{4}=973.11 \mathrm{~cm}^{2} \\
A_{a}^{\text {profil }}=\frac{41.6^{2} \pi}{4}-\frac{40^{2} \pi}{4}=102.54 \mathrm{~cm}^{2} \\
A_{s}=12 \frac{2.2^{2} \pi}{4}=45.62 \mathrm{~cm}^{2}
\end{gathered}
$$

Coefficient of safety for the base load: $\gamma_{0}=1.7$

Active stiffness on bending of the composite column:

$\mathrm{Ea}=21000 \mathrm{kN} / \mathrm{cm} 2$

$$
\begin{gathered}
(E I) w=E_{a} I_{a}+E_{b i} I_{b}+E_{s} I_{s} \\
I_{a}=\frac{\left(41.6^{4}-40^{4}\right) \pi}{64}=21345.06 \mathrm{~cm}^{4}
\end{gathered}
$$

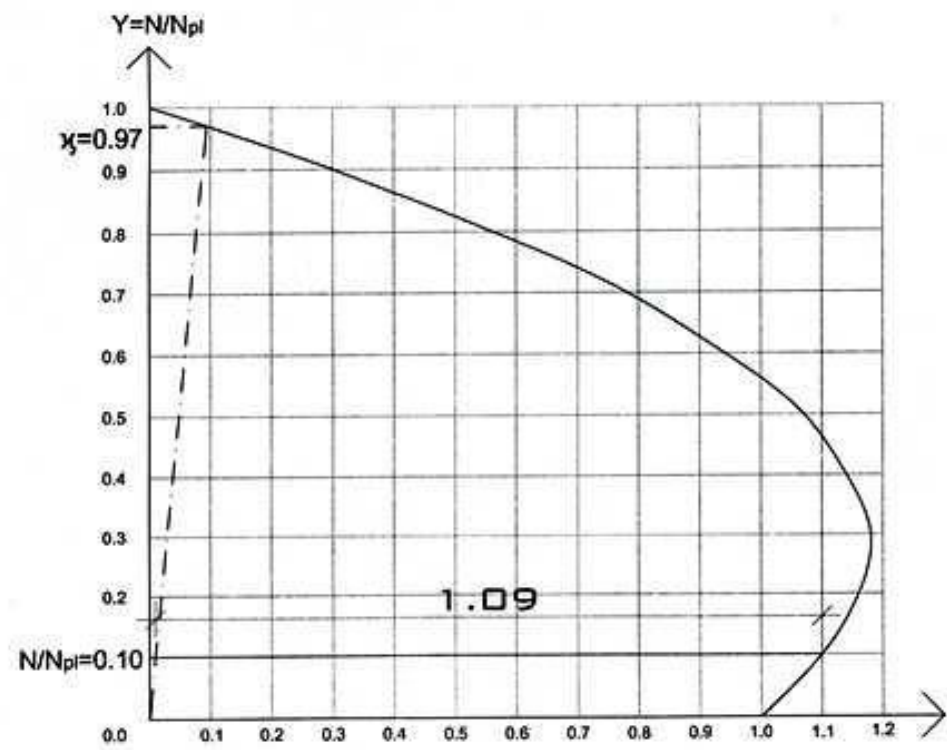

$\mathrm{X}=\mathrm{M} / \mathrm{Mpl}$

Figure 11. Interactional diagram of the composite column

\section{Rehabilitation measures}

Applied rehabilitation measures are the result of the test program with the aim of protecting the 
existing piles from adverse impacts of water and also to return the resulting buckling length to the projected norm of $5.0 \mathrm{~m}$. Protection of the piles was carried out by refuting Larsen talpe $604 \mathrm{n}$.

Columns rehabilitation in 5th, 6th and 7th rows. The large number of cracks is present in these columns, so reinforcement is performed on the columns with steel having the thickness $\delta=8,0 \mathrm{~mm}$, throughout the height of the columns. The columns are calculated as a couple, with the existing crosssection of MB 30. From the interactional curve above, it is clear that the performed reinforcement raised load capacity with very small changes in geometry as in width, and height [39-42].

Details of the foundation rate at the same time represents reinforcement of the piles as well as the nominal supports of the newly designed composite columns (Fig. 12).

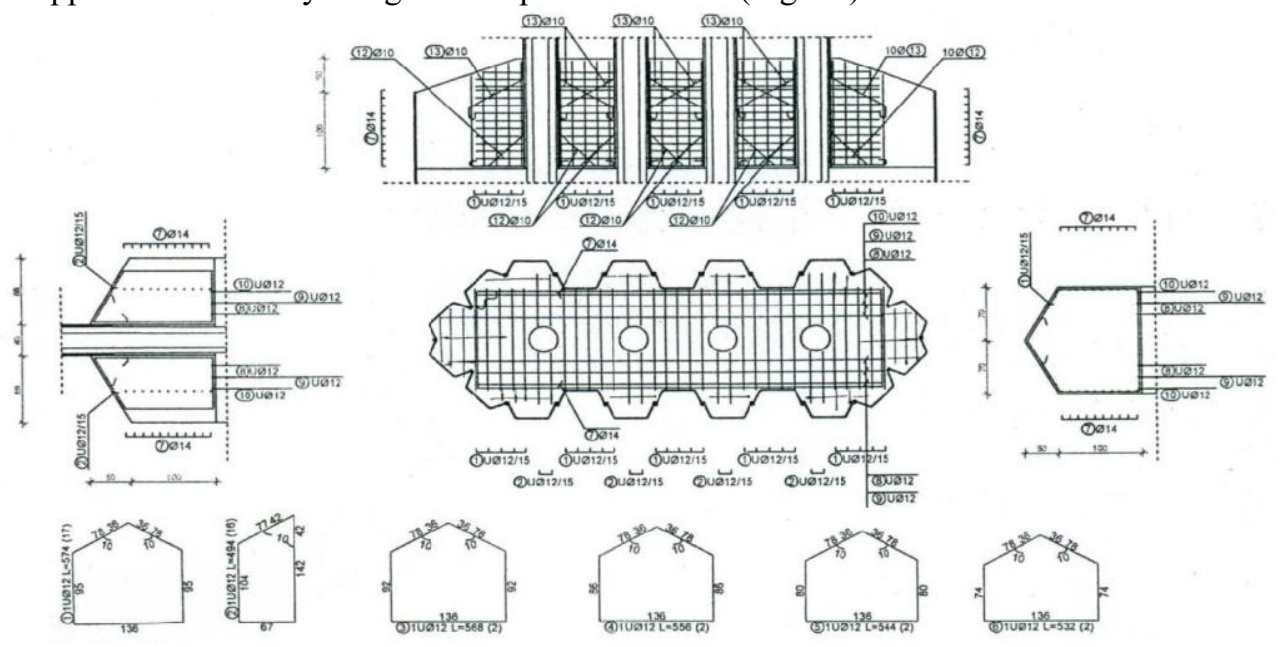

Figure 12. Details of the reinforced foundational rate

\section{Summary}

Systematic and complex testing of bridges allows timely notice of dangerous irregularities in their structure. Properly implemented, the rehabilitation measures are able to fully establish the performance of a bridge and thus to extend the term of their exploitation.

\section{References}

1. EN, Design of composite steel and concrete structures, (1994)

2. PBAB 87 Rules for concrete i reinforced concrete (2013)

3. Grinfeldi, G., A. S. Gorshkov, N. I. Vatin, Advanced Materials Research, 941-944, 786-799, (2014)

4. Mandić, R., Hadži-Niković, G., Ćorić, S., Geofizika, 28 (1), 145-160 (2011)

5. R. Usmanov, V. Murgul, N. Vatin, Applied Mechanics and Materials, 633-634, 1082-1085 (2014)

6. R. Kamnik, B. Kovačič, B. Pribicević, A. Đapo, Geodetski List, 69 (3), 171-188 (2015)

7. B. Kovačič, R. Kamnik, A. Štrukelj, N. Vatin, Procedia Engineering, 117 (1), 800-806 (2015)

8. R. Usmanov, M. Rakočević, V. Murgul, N. Vatin, Applied Mechanics and Materials, 633-634, 927-931 (2014)

9. B. Kovačič, R. Kamnik, M. Premrov, Survey Review, 43 (320), 150-161 (2011)

10. Z. Radovanović, R. Sinđić Grebović, S. Dimovska, N. Serdar, N. Vatin, V. Murgul, Procedia Engineering, 117, 870-878 (2015)

11. B. Kovačič, R. Kamnik, A. Štrukelj, Promet - Traffic - Traffico, 22 (1), 15-22 (2010)

12. B. Kovačič, R. Kamnik, Z. Kapović, Geodetski List, 63 (4), 315-327 (2009) 
13. N. Gubeljak, J. Predan, D. Kozak, J. Tuma, B. Kovačič, P. Konjatić, J. Sertić, Strojarstvo, 51 (4), 263-271 (2009)

14. B. Kovačič, R. Kamnik, M. Premrov, N. Gubeljak, J. Predan, Z. Tišma, Strojniski Vestnik/Journal of Mechanical Engineering, 54 (5), 364-371 (2008)

15. B. Kovačič, R. Kamnik, International Journal for Engineering Modelling, 20 (1-4), 77-84 (2007).

16. B. Kovačič, B. Supej, (2004) Geodetski Vestnik, 48 (1), 40-49 (2004)

17. B . Kovačič, B. Geodetski Vestnik, 48 (1), 32-39 (2004).

18. V.V Okrepilov, A.Yu. Smirnov, Measurement Techniques, 56 (1), 54-60 (2013)

19. V.V Okrepilov, Studies on Russian Economic Development, 24(1), 35-42 (2013)

20. V.V Okrepilov, Standarty i Kachestvo, 10, 52-55 (2005)

21. V.V Okrepilov, Ivanova, G. Standarty i Kachestvo, 12, 62-68. (2004)

22. V.V Okrepilov, Standarty i Kachestvo, 3, 94-96. (2003)

23. N. Vatin, N. Lavrov, A. Shipilov, Procedia Engineering, 117 (1), 374-380 (2015)

24. J. Ćetković, S. Rutešić, M. Zarković, M. Knežević, N. Vatin, Procedia Engineering, 117 (1), 780 $790(2015)$

25. S.G. Popović, S. Vukanić, D.F. Komatina, E. Alihodzic-Jasarevic, N. Vatin, Procedia Engineering, 117 (1), 614-620 (2015)

26. S. Ognjenovic, Z. Krakutovski, N. Vatin, Procedia Engineering, 117 (1), 564-572 (2015)

27. S. Ognjenovic, R. Donceva, N. Vatin, Procedia Engineering, 117 (1), 556-563 (2015)

28. B. Stamatovic, R. Upadhyay, Procedia Engineering, 117 (1), 660-667 (2015)

29. Z.Popović, L. Lazarevic, N. Vatin, Procedia Engineering, 117 (1), 846-853 (2015)

30. S. Ognjenovic, R. Ristov, N. Vatin, (2015) Procedia Engineering, 117 (1), 575-578 (2015)

31. S. Rutešić, J. Ćetković, M. Žarcković, M. Knežević, N. Vatin, Procedia Engineering, 117 (1), 905-915 (2015)

32. V. Korsun, N. Vatin, A. Franchi, A. Korsun, P. Crespi, Mashtaler S. Procedia Engineering, 117 (1), 975-984 (2015)

33. S. Ognjenovic, R. Donceva, N. Vatin, Procedia Engineering, 117 (1), 549-555 (2015)

34. Procedia Engineering, 117 (1), 924-937 (2015)

35. S. Ognjenovic, Z. Zafirovski, N. Vatin, Procedia Engineering, 117 (1), 579-584 (2015)

36. B. Melović, S. Mitrović, A. Djokaj, N. Vatin, Procedia Engineering, 117 (1), 807-812 (2015)

37. S. Rutešić, J. Ćetković, M. Knežević, M. Žarcković, N. Vatin, Procedia Engineering, 117 (1), 642-650 (2015)

38. N. Vatin, J. Havula, L. Martikainen, A. Sinelnikov, A. Orlova, S. Salamakhin, Advanced Materials Research, 945-949, 1211-1215 (2014)

39. N. Vatin, T. Nazmeeva, R. Guslinscky, Advanced Materials Research, 941-944, 1871-1875 (2014)

40. N. Vatin, A. Sinelnikov, M. Garifullin, D. Trubina, Applied Mechanics and Materials, 633-634, 1037-1041 (2014)

41. D.Arseniev, A. Rechinskiy, K.Shvetsov, N. Vatin, O. Gamayunova, Applied Mechanics and Materials, 635-637, 2076-2080 (2014)

42. V.Chechevichkin, N. Vatin, Applied Mechanics and Materials, 641-642, 409-415 (2014) 